\title{
Synthesis of $\beta$-SiAlON from a zeolite by reduction nitridation in a mixture of $\mathrm{NH}_{3}-\mathrm{C}_{3} \mathrm{H}_{8}$
}

\author{
Tomohiro YAMAKAWA, Toru WAKIHARA, Junichi TATAMI, \\ Katsutoshi KOMEYA and Takeshi MEGURO
}

Graduate School of Environment and Information Sciences, Yokohama National University, 79-7, Tokiwadai, Hodogaya-ku, Yokohama 240-8501

\begin{abstract}
Gas reduction-nitridation (GRN), which uses a mixture of $\mathrm{NH}_{3}$ and carbohydrate as a reactant gas, has been proposed a synthetic technique for producing high-purity nitride powders. In this study, $\beta$-SiAlON powder was produced from zeolite using GRN. Zeolite was used directly as the raw material without previous preparation or handling. It was found that high purity $\beta$-SiAION nanopowder was synthesized at $1400^{\circ} \mathrm{C}$ for $60 \mathrm{~min}$. Furthermore, pure $\beta$-SiAlON was successfully produced, containing no minor phases, by the optimization of nitridation, that is, of concentration of $\mathrm{C}_{3} \mathrm{H}_{8}$ and the timing of its introduction.
\end{abstract}

Key-words: $\boldsymbol{\beta}$-SiAION, Zeolite, Gas reduction-nitridation, Nano powder

[Received October 6, 2007; Accepted January 17, 2008] @2008 The Ceramic Society of J apan

\section{Introduction}

SiAlON ceramics are promising engineering materials because of their excellent properties, e.g. high fracture toughness, high strength and corrosion resistance close to $\beta$ - $\mathrm{Si}_{3} \mathrm{~N}_{4} \cdot \beta$-SiAlON is a solid solution of $\beta-\mathrm{Si}_{3} \mathrm{~N}_{4}$ in which some $\mathrm{Si}$ and $\mathrm{N}$ are replaced by $\mathrm{Al}$ and $\mathrm{O}$. Its stoichiometric composition depends on the solid solubility limit. The chemical formula is as follows;

$$
\mathrm{Si}_{6-z} \mathrm{Al}_{z} \mathrm{O}_{z} \mathrm{~N}_{8-z} \quad(0<z<4.2)
$$

$\beta$-SiAlON ceramics are commonly produced by the reaction sintering of mixtures of $\mathrm{Si}_{3} \mathrm{~N}_{4}, \mathrm{AlN}$, and $\mathrm{Al}_{2} \mathrm{O}_{3}$ over at $1500^{\circ} \mathrm{C}$. As its corrosion resistance lowers with the formation of its glassy phase in the sintered body, the preparation of $\beta$-SiAlON powder and its sintering using spark plasma sintering (SPS $)^{1)}$ has received considerable attention as it avoids the formation of glassy phase in the grain boundary.

$\beta$-SiAlON powder is mostly synthesized from mixtures of $\mathrm{SiO}_{2}$ and $\mathrm{Al}_{2} \mathrm{O}_{3}$ by carbothermal reduction-nitridation (CRN) over at $1400^{\circ} \mathrm{C}$. The suitability of various minerals as raw materials for this process has been widely investigated. These include such as kaolinite, ${ }^{2)}{ }^{-6)}$ halloysite, ${ }^{6), 7)}$ montmorillonite $^{8)}$ and bentonite. ${ }^{9)}$ These minerals are mainly composed of $\mathrm{Si}$ and $\mathrm{Al}$, and contain them uniformly on an atomic scale; however, due to the effects of the contamination and the difficulty of controlling the compositions, for example the $\mathrm{Si} / \mathrm{Al}$ ratio, in the raw materials, products synthesized using these minerals consequently contain AIN, mullite and $15 \mathrm{R}$ polytype as impurity phases. The work presented here focuses on using a zeolite as a raw material to avoid these problems. Zeolites are hydrated, crystalline, tectoaluminosilicates constructed from $\mathrm{TO}_{4}$ tetrahedra (where $T=$ tetrahedral atom, e.g. Si and $\mathrm{Al}) .^{10)-12}$ They contain well-ordered, nanometer-sized void spaces (ca. $0.3-1.5 \mathrm{~nm}$ ) in their structures. Furthermore, it is possible to control the $\mathrm{Si} / \mathrm{Al}$ ratio of zeolites by controlling the starting composition. It is also easy to incorporate charge compensation cations (e.g. $\mathrm{Na}^{+}, \mathrm{Ca}^{2+}$ and $\mathrm{H}^{+}$) uniformly in zeolite struc- tures by ion exchange since the structure contains many anionic Al sites. Sugahara et al. ${ }^{13}$ ) synthesized $\beta$-SiAlON from compounds containing zeolite-polyacrylonitrile by the CRN process; they showed the suitability of zeolite as a raw material, but the formation of high-purity $\beta$-SiAlON could not be performed by the technique discussed. In a previous study, ${ }^{14)}$ high-purity $\beta$-SiAlON was synthesized from a mixture of zeolite and carbon by the CRN process; however, the resultant products had a large distribution in $z$ value since the composition of the glassy phase became inhomogeneous due to the formation of mullite during firing.

In recent years, gas reduction-nitridation (GRN), which uses a mixture of $\mathrm{NH}_{3}$ and carbohydrate as a reactant gas, has been proposed a synthetic technique for producing highpurity nitride powders. ${ }^{15)}$-19) The GRN process is quite a simple process since it does not require mixing, milling or a decarburization process. Moreover, the GRN process is generally performed at lower temperatures and with less solid solution of carbon in the products than the CRN process. In this paper, $\beta$-SiAlON powder is synthesized from a zeolite by the GRN process, producing highly-pure $\beta$-SiAlON composed nanoparticles $(<100 \mathrm{~nm})$.

\section{Experimental}

Zeolite Y (HSZ-330HUA, Toso Chem. Co., Tokyo) was used as a starting material since zeolite $\mathrm{Y}$ is one of the most representative zeolites and is able to be synthesized with wide range of $\mathrm{Si} / \mathrm{Al}$ ratio (from 1.5 to $\infty$ ). The main characteristics of the raw powder are listed in Table 1. The raw powder was weighed into an alumina boat, placed in an electric furnace with a high-purity alumina work tube, and then fired to $700^{\circ} \mathrm{C}$ at a heating rate of $5^{\circ} \mathrm{C} / \mathrm{min}$. The powder was heated in Ar gas (99.999\% purity) in order to eliminate oxygen in the system and remove the absorption water in the zeolite. It was confirmed that the structure of the zeolite did not change during the pre-heating process up to $700^{\circ} \mathrm{C}$. Heating was continued in a flowing gas mixture $(4 \mathrm{l} / \mathrm{min})$ of $\mathrm{NH}_{3}$ (99.999\% purity) and $\mathrm{C}_{3} \mathrm{H}_{8}(99.99 \%$ purity, $0.5 \mathrm{vol} \%)$. The 
Table 1. Characteristics of the Raw Powder

\begin{tabular}{lc}
\hline \multicolumn{1}{c}{ Characteristics } & Value \\
\hline Zeolite type & Y-type \\
$\mathrm{Si} / \mathrm{Al}(\mathrm{mol} / \mathrm{mol})$ & $3(\mathrm{z}=1.5)$ \\
Mean particle size $(\mu \mathrm{m})$ & $0.6 \%$ \\
Specific surface area $\left(\mathrm{m}^{2} \mathrm{~g}^{-1}\right)$ & 550 \\
\hline As provided by the supplier. &
\end{tabular}

sample was heated to the reaction temperature of 1200 $1400^{\circ} \mathrm{C}$ at a rate of $8^{\circ} \mathrm{C} / \mathrm{min}$ and held for $0-60 \mathrm{~min}$ before being cooled in $\mathrm{NH}_{3}$. Note that in some cases, the effect of the timing of the introduction of $\mathrm{C}_{3} \mathrm{H}_{8}$ was investigated and in others $\mathrm{C}_{3} \mathrm{H}_{8}$ was introduced at $1200^{\circ} \mathrm{C}, 1300^{\circ} \mathrm{C}$ and $1400^{\circ} \mathrm{C}$, respectively.

For comparison, the $\mathrm{CRN}$ process was performed using the same zeolite as a raw material. ${ }^{14)}$ At first, zeolite was mixed with carbon (650B, Mitsubishi Chemical Co., Ltd.). The carbon content was fixed at 1.2 times the required stoichiometric value. The mixture was milled without solvent for $36 \mathrm{~h}$, and was subsequently ground and passed through a sieve with 50-mesh holes. $1.0 \mathrm{~g}$ of the sample was placed on a carbon boat and was fired in a furnace at $1450^{\circ} \mathrm{C}$ for $120 \mathrm{~min}$ in $\mathrm{N}_{2}$ flow $(0.5 \mathrm{l} / \mathrm{min})$. The heating rate was set at approximately $12^{\circ} \mathrm{C} / \mathrm{min}$. The residual carbon was removed by burning the resultant powders at $700^{\circ} \mathrm{C}$ for $120 \mathrm{~min}$ in atmospheric conditions. Further, a mixture of $\mathrm{SiO}_{2}$ (QS-102 Tokuyama Co., Ltd)) and $\mathrm{Al}_{2} \mathrm{O}_{3}$ (Boehmite, AD220P, Tomita Pharmaceutical Co. Ltd), with the same composition as raw zeolite, was also prepared ${ }^{20)}$ and nitrided by GRN process.

The phases present in the products were identified by X-ray diffractometry (RINT2500, Rigaku, Tokyo) using $\mathrm{CuK} \alpha$ radiation operated at $50 \mathrm{kV}$ and $300 \mathrm{~mA}$. Changes in the morphologies were observed by transmission electron microscope (JEM-2000FX, JEOL, Tokyo). The specific surface areas of the products were measured by single-point of Brunauer-Ematt-Teller method (BET; Quantasorb, Quantachrome, Boynton Beach, FL).

\section{Results and discussion}

Figure 1 shows XRD patterns of the products synthesized at $1200^{\circ} \mathrm{C}$ for $0 \mathrm{~min}, 1400^{\circ} \mathrm{C}$ for $0 \mathrm{~min}$ and $1400^{\circ} \mathrm{C}$ for $60 \mathrm{~min}$ from raw zeolite, the product synthesized by the CRN process from raw zeolite and the product synthesized from $\mathrm{SiO}_{2}-\mathrm{Al}_{2} \mathrm{O}_{3}$ mixture by the GRN process. It was found that raw zeolite was transformed into its amorphous phase at $1200^{\circ} \mathrm{C}$ (Fig. 1b) and $O^{\prime}$-SiAlON and $X^{\prime}$-SiAlON as intermediate phases were confirmed in the sample synthesized at $1400^{\circ} \mathrm{C}$ for $0 \mathrm{~min}$ (Fig. 1c), matching results reported in a previous study. ${ }^{6}$ Finally, high-purity $\beta$-SiAlON was obtained by the heat treatment at $1400^{\circ} \mathrm{C}$ for $60 \mathrm{~min}$ as shown in Fig. 1d. Figure 1e shows the XRD pattern of the sample prepared by the CRN process. It is found that high purity $\beta$-SiAlON can also be synthesized by the CRN process; however the peak of $\beta$-SiAlON is broadened as indicated in the arrow in Fig. 1e; indicating that the resultant products have a large distribution of $z$ values because of the formation of a $\mathrm{Si}$ rich amorphous phase and $\mathrm{Al}$ rich mullite phase in products formed during firing and subsequent

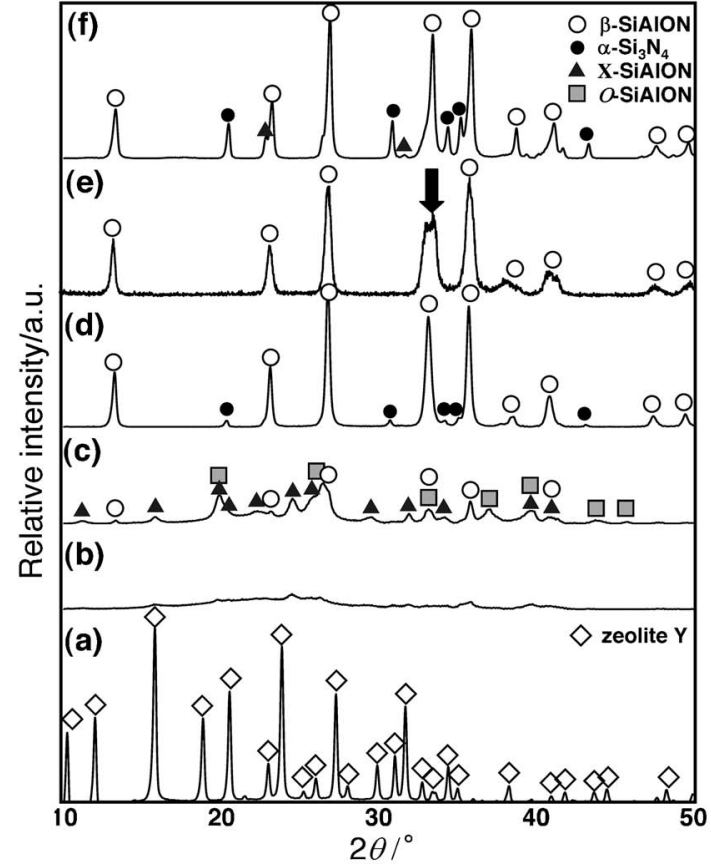

Fig. 1. XRD patterns of (a) raw zeolite, (b) the product synthesized at $1200^{\circ} \mathrm{C}$ for $0 \mathrm{~min}$, (c) $1400^{\circ} \mathrm{C}$ for $0 \mathrm{~min}$ and (d) $1400^{\circ} \mathrm{C}$ for $60 \mathrm{~min}$. For comparison, XRD patterns of (e) the product synthesized by the CRN process and (f) the product synthesized from $\mathrm{SiO}_{2}-\mathrm{Al}_{2} \mathrm{O}_{3}$ mixture by the GRN process are shown. The arrow indicates the product has a large distribution of $z$ values.

crystallization to $\beta$-SiAlON. ${ }^{21)}$ Figure $1 \mathrm{f}$ shows the XRD pattern of the product prepared from $\mathrm{SiO}_{2}-\mathrm{Al}_{2} \mathrm{O}_{3}$ mixture. It was found that $\alpha-\mathrm{Si}_{3} \mathrm{~N}_{4}$ represents a considerable impurity phase when compared to using zeolite as a raw material (Fig. 1d). This result can be ascribed to inhomogeneous distributions of $\mathrm{Si}$ and $\mathrm{Al}$ atoms in the $\mathrm{SiO}_{2}-\mathrm{Al}_{2} \mathrm{O}_{3}$ mixture. It is known that $\mathrm{SiO}$ gas is formed in a reducing atmosphere around $1400^{\circ} \mathrm{C}^{22)-24)}$ Because the $\mathrm{Si}$ and $\mathrm{Al}$ atoms are not distributed uniformly on an atomic scale in the $\mathrm{SiO}_{2}-\mathrm{Al}_{2} \mathrm{O}_{3}$ mixture, $\mathrm{SiO}$ gas is easily formed and reacts with $\mathrm{NH}_{3}$. As a result, a larger volume of $\alpha-\mathrm{Si}_{3} \mathrm{~N}_{4}$ is formed as indicated in the following equations.

$$
\begin{aligned}
& \mathrm{SiO}_{2}+2 \mathrm{NH}_{3} \longrightarrow \mathrm{SiO}+\mathrm{N}_{2}+\mathrm{H}_{2} \mathrm{O}+2 \mathrm{H}_{2} \\
& 3 \mathrm{SiO}+4 \mathrm{NH}_{3} \longrightarrow \mathrm{Si}_{3} \mathrm{~N}_{4}+3 \mathrm{H}_{2} \mathrm{O}+3 \mathrm{H}_{2}
\end{aligned}
$$

On the other hand, since $\mathrm{Si}$ and $\mathrm{Al}$ atoms are mixed uniformly on an atomic scale in zeolite, it is thought that formation of $\mathrm{SiO}$ gas is prevented by well-dispersed $\mathrm{Al}$ atoms in the amorphous phase, suppressing $\alpha-\mathrm{Si}_{3} \mathrm{~N}_{4}$ formation. The vapor pressure of $\mathrm{AlO}$ gas is extremely low compared with $\mathrm{SiO}$ gas. We think that the vapor pressure of $\mathrm{SiO}$ decreases by the vapor pressure depression because a lot of $\mathrm{Al}$ atom exists. ${ }^{25)}$ It can be concluded that high purity $\beta$-SiAlON with shaper $z$ value distribution than that obtained by the CRN process was successfully synthesized from zeolite $\mathrm{Y}$ by the GRN process.

TEM photographs of the products synthesized at $1200^{\circ} \mathrm{C}$ for $0 \mathrm{~min}, 1400^{\circ} \mathrm{C}$ for $0 \mathrm{~min}$ and $1400^{\circ} \mathrm{C}$ for $60 \mathrm{~min}$, together with a photograph of raw material are shown in Fig. 2. It was found that well-facetted zeolite particles were changed to a beadlike morphology at $1400^{\circ} \mathrm{C}$ for $0 \mathrm{~min}$. TEM image, 

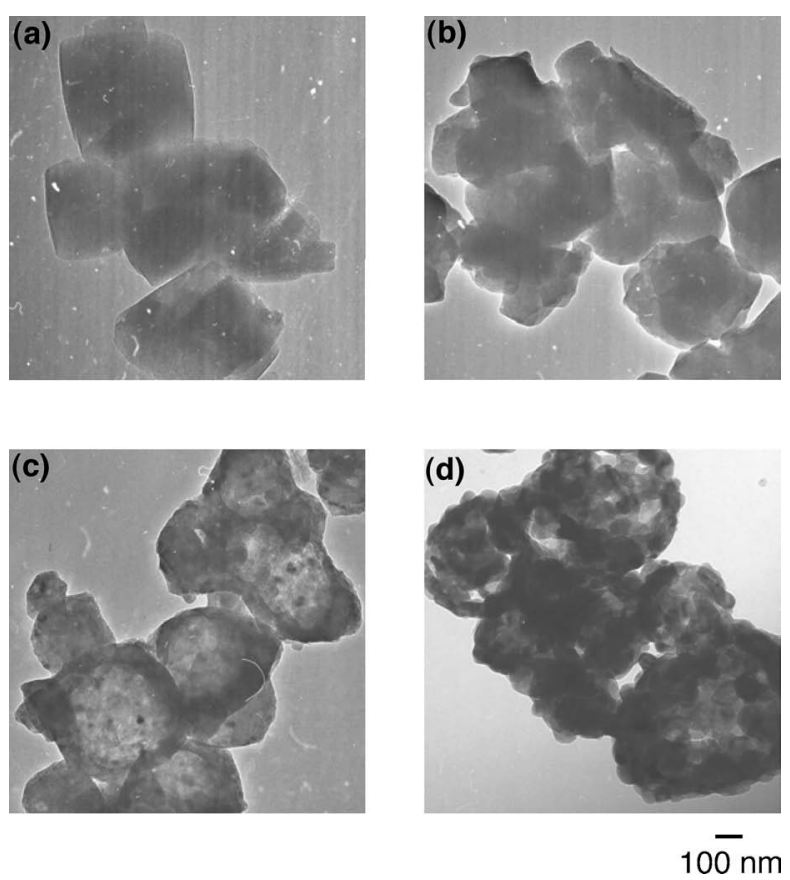

Fig. 2. TEM photographs of raw material (a) and the products synthesized at $1200^{\circ} \mathrm{C}$ for $0 \mathrm{~min}(\mathrm{~b}), 1400^{\circ} \mathrm{C}$ for $0 \mathrm{~min}$ (c) and $1400^{\circ} \mathrm{C}$ for $120 \mathrm{~min}(\mathrm{~d})$.

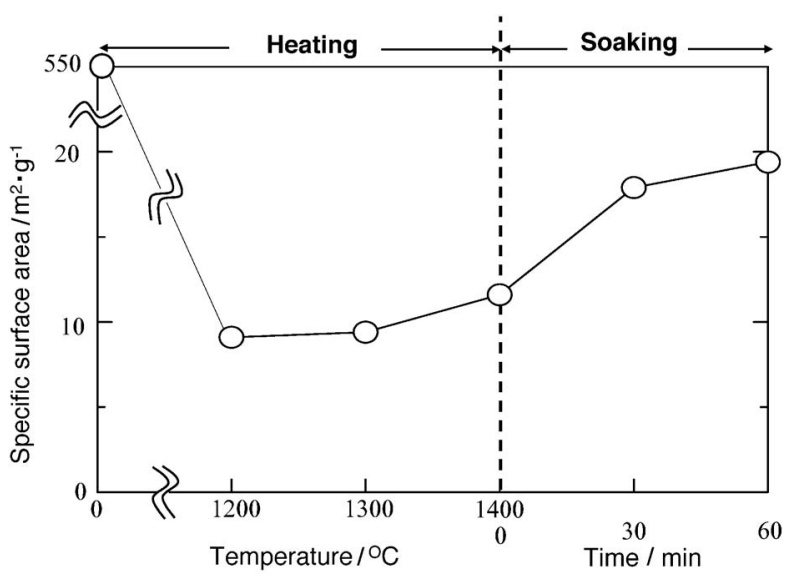

Fig. 3. Specific surface areas of the products synthesized at various reaction temperatures at $1200-1400^{\circ} \mathrm{C}$ for $0-120 \mathrm{~min}$.

as shown in Fig. 2b, of particle morphologies of the resulting powders at $1400^{\circ} \mathrm{C}$ for 60 min shows that generated particles exhibited hollow spheres approximately $200-500 \mathrm{~nm}$ in diameter, these being produced mainly from ultrafine initial particles of 50-100 nm. In previous research, similar morphology has been confirmed in the synthesis of $\mathrm{Ca} \alpha$ SiAlON. ${ }^{26)}{ }^{27)}$ It is thought that hollow spheres are formed by the nucleation of $\beta$-SiAlON and intermediate phases on the surface of each particle and the subsequent mass transfer due to crystal growth and/or by the generation of $\mathrm{H}_{2} \mathrm{O}$ and $\mathrm{CO}$ gas during nitridation. Figure 3 shows the specific surface areas of the products synthesized at 1200, 1300 and $1400^{\circ} \mathrm{C}$ without holding time, and at $1400^{\circ} \mathrm{C}$ with 30 and 60 min holding. It was obtained that the specific surface area of

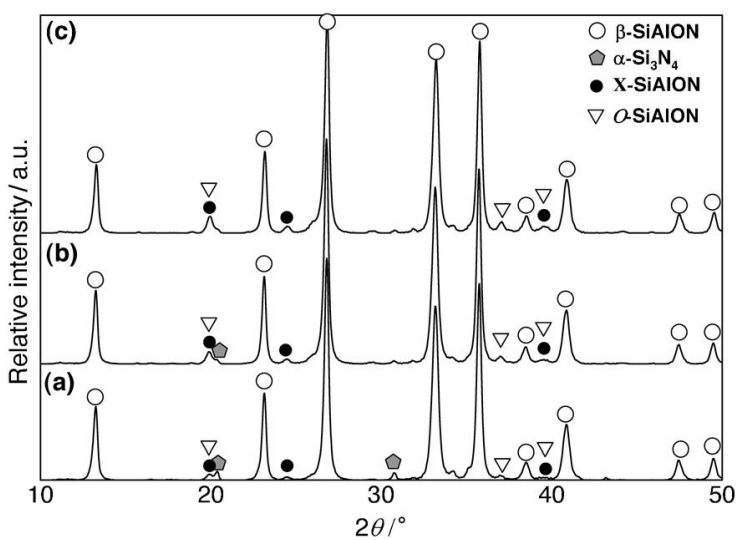

Fig. 4. Effect of concentration of $\mathrm{C}_{3} \mathrm{H}_{8}$ on the phase compositions of the products by GRN process fired at $1400^{\circ} \mathrm{C}$ for $30 \mathrm{~min}$. (a) 0.25 , (b) 0.05 and (c) $0.025 \mathrm{vol} \%$.

a raw material was drastically decreased by introducing amorphization. However, it was found that the specific surface area was increased from 9.1 up to $19.4 \mathrm{~m}^{2} / \mathrm{g}$ during the GRN process. Therefore it is concluded that the specific surface area increases with the production of $\beta$-SiAlON. This conclusion agrees with those obtained by XRD and TEM as shown in Figs. 1 and 2, respectively. Figure 4 shows the effect of $\mathrm{C}_{3} \mathrm{H}_{8}$ concentration on the phase compositions of the materials produced by the GRN process fired at $1400^{\circ} \mathrm{C}$ for $30 \mathrm{~min}$. The presence of $O^{\prime}-\mathrm{SiAlON}$ and $X^{\prime}$-SiAlON was confirmed in conditions with lower $\mathrm{C}_{3} \mathrm{H}_{8}$ concentrations. As the concentration of $\mathrm{C}_{3} \mathrm{H}_{8}$ increased, phase contents of $O^{\prime}$ SiAlON and $X^{\prime}$-SiAlON decreased and formation of $\alpha-\mathrm{Si}_{3} \mathrm{~N}_{4}$ was confirmed. $\mathrm{C}_{3} \mathrm{H}_{8}$ plays the role of reducing agent, promoting nitridation, that is, the formation of $\mathrm{N}-\mathrm{T}(-\mathrm{T})$ $(-\mathrm{T})$ bonds from $\mathrm{T}-\mathrm{O}-\mathrm{T}$ bonds $(\mathrm{T}=\mathrm{Si}$ and $\mathrm{Al})$. In conditions with lower $\mathrm{C}_{3} \mathrm{H}_{8}$ concentrations, $O^{\prime}$-SiAlON and $X^{\prime}$ SiAlON, which are stable phases at lower temperatures, still remain in the samples since nitridation of the aluminosilicate amorphous phase is not greatly promoted. On the other hand, reduction nitridation of the aluminosilicate amorphous phase is promoted in conditions with higher $\mathrm{C}_{3} \mathrm{H}_{8}$ concentrations as indicated in the following equation.

$$
\mathrm{SiO}_{2} \text { (in zeolite) }+\mathrm{C}\left(\text { in } \mathrm{C}_{3} \mathrm{H}_{8}\right) \longrightarrow \mathrm{SiO}+\mathrm{CO}
$$

The $\mathrm{SiO}$ gas formed reacts with $\mathrm{NH}_{3}$ to form $\alpha-\mathrm{Si}_{3} \mathrm{~N}_{4}$ as follows.

$$
3 \mathrm{SiO}+4 \mathrm{NH}_{3} \longrightarrow \mathrm{Si}_{3} \mathrm{~N}_{4}+3 \mathrm{H}_{2} \mathrm{O}+3 \mathrm{H}_{2}
$$

It appears, therefore, that formation of $\alpha-\mathrm{Si}_{3} \mathrm{~N}_{4}$ as a minor phase is promoted in conditions with higher $\mathrm{C}_{3} \mathrm{H}_{8}$ concentrations.

Figure 5 shows the effect of $\mathrm{C}_{3} \mathrm{H}_{8}$ injection timing on the phase compositions of the materials produced by the GRN process fired at $1400^{\circ} \mathrm{C}$ for $30 \mathrm{~min} . \mathrm{C}_{3} \mathrm{H}_{8}$ was introduced at 1200,1300 and $1400^{\circ} \mathrm{C}$ before the holding period. It was found that when the introduction of $\mathrm{C}_{3} \mathrm{H}_{8}$ was delayed to 1300 and $1400^{\circ} \mathrm{C}$, nitridation did not complete and as a result $O^{\prime}$-SiAlON and $X^{\prime}$-SiAlON were formed. On the other hand, pure $\beta$-SiAlON was successfully obtained when $\mathrm{C}_{3} \mathrm{H}_{8}$ was introduced at $1200^{\circ} \mathrm{C}$. We think that the generation of the $\mathrm{SiO}$ gas is suppressed due to the rapid nitridation reaction influenced by the introduced $\mathrm{C}_{3} \mathrm{H}_{8}$ gas at the low 


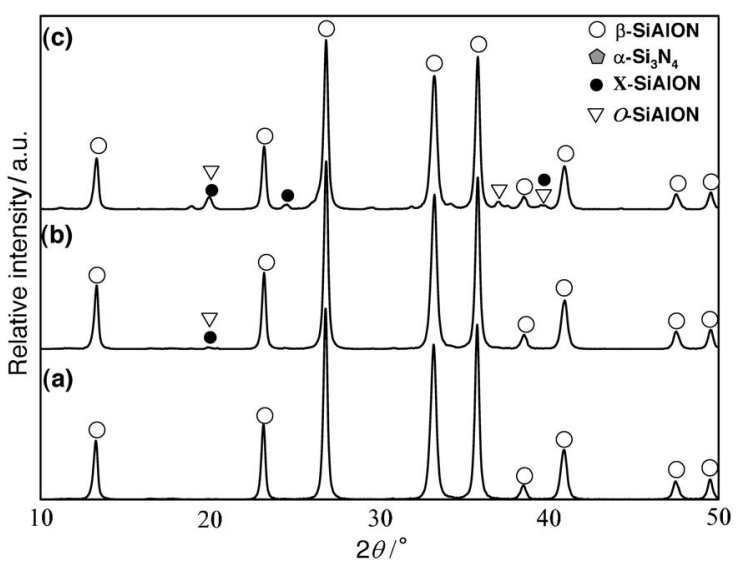

Fig. 5. Effect of $\mathrm{C}_{3} \mathrm{H}_{8}$ injection timing on phase compositions of the products by GRN process fired at $1400^{\circ} \mathrm{C}$ for $30 \mathrm{~min} . \mathrm{C}_{3} \mathrm{H}_{8}$ was introduced at (a) 1200 , (b) 1300 and (c) $1400^{\circ} \mathrm{C}$ before the holding period.

temperature. Whereas at high temperatures of $1300^{\circ} \mathrm{C}$ and $1400^{\circ} \mathrm{C}$, we think that $\alpha-\mathrm{Si}_{3} \mathrm{~N}_{4}$ has already nucleated before passing the $\mathrm{C}_{3} \mathrm{H}_{8}$. It is thought that crystallization of $\alpha-\mathrm{Si}_{3} \mathrm{~N}_{4}$ is promoted even if the reaction time is long. It may be that formation of $\alpha-\mathrm{Si}_{3} \mathrm{~N}_{4}$ has relation with a heat treatment time. These was concluded, therefore, that it is possible to produce pure $\beta$-SiAlON without any minor phases by the optimization of nitridation; that is, optimizing both the concentration, and timing, of introduction of $\mathrm{C}_{3} \mathrm{H}_{8}$.

\section{Conclusions}

High purity $\beta$-SiAlON powder was produced from zeolite using gas-reduction-nitridation. Zeolite was used directly as the raw material without previous preparation or handling. It was found that high purity $\beta$-SiAlON nanopowder was synthesized at $1400^{\circ} \mathrm{C}$ for $60 \mathrm{~min}$, and that the powder was comprised of hollow spheres which formed from the initial particles with diameters of about $30-50 \mathrm{~nm}$. Furthermore, pure $\beta$-SiAlON was successfully produced, containing no minor phases, by the optimization of nitridation, that is, of concentration of $\mathrm{C}_{3} \mathrm{H}_{8}$ and the timing of its introduction.

\section{References}

1) Q Li, K. Komeya, J. Tatami, T. Meguro and L. Gao, Key Eng. Mater., 247, 75-78 (2006).

2) H.-L. Lee, H.-J Lim, S. Kim and H.-B. Lee, J. Am. Ceram. Soc., 72, 1458-1461 (1989).

3) M. Vlasova, V. B. Vinokurov, O. N. Grigo'ev, A. D.
Panasyuk, N. D. Bega, M. Kakazey, J. G. G.-Rodriguez, G. D.-Patiňo and M. D.-Patiňo, Mat. Sci. Eng., A366, 325-331 (2004).

4) Y. W. Cho and J. A. Charles, Mater. Sci. Eng., 7, 399-406 (1991).

5) X.-J. Liu, X. W. Sun, J. J. Zhang, X. P. Pu, Q. M. Ge and L. P. Huang, Mater. Res. Bull., 38, 1939-48 (2003).

6) K. J. D. Mackenzie, R. H. Meinhold, G. V. White and C. M. Sheppard., J. Mater. Sci., 29, 2611-2619 (1994).

7) M. E. Bowden, K. J. D. MacKenzie and J. H. Johnston, Material Sci. Forlum., 34-36, 599-603 (1988).

8) Y. Sugahara, K. Kuroda and C. Kato., J. Am. Ceram. Soc., 72, C247-248 (1984).

9) A. D. Mazzoni and E. F. Aglietti, Appl. Clay. Sci., 17, 127-140 (2000).

10) R. M. Barrer, Hydrothermal Chemistry of Zeolites, Academic Press, London, 1982.

11) C. S. Cundy and P. A. Cox, Chem. Rev., 103, 663 (2003).

12) T. Wakihara and T. Okubo, Chem. Lett., 34, 276-281 (2005).

13) Y. Sugahara, H. Hiraiwa, K. Kuroda and C. Kato, J. Mat. Sci., 23, 3181-3186 (1988).

14) F. J. Li, J. Tatami, T. Meguro and K. Komeya, Key. Eng. Mater., 247, 109-112 (2003).

15) T. Yamakawa, T. Wakihara, J. Tatami, K. Komeya and T. Megro, Ceram. Trans., 190, 3-8 (2006).

16) T. Suehiro, J. Tatami, T. Megro, S. Matsuo and K. Komeya, J. Eur. Ceram. Soc., 85, 715-717 (2002).

17) T. Yamakawa, J. Tatami, T. Wakihara, T. Meguro, K. Komeya, K. J. D. MacKenzie, S. Takagi and M. Yokouchi, J. Am. Ceram. Soc., 89[1], 171-175 (2006).

18) T. Yamakawa, J. Tatami, T. Wakihara, T. Meguro, K. Komeya and K. J. D. MacKenzie, Key Eng. Mater., 317-18, 215-218 (2006).

19) T. Yamakawa, J. Tatami, K. Komeya and T. Meguro, J. Eur. Ceram. Soc., 26(12), 2413-2418(2006).

20) Q. Li, C. Zhang, K. Komeya, J. Tatami, T. Meguro and L. Gao, Key. Eng. Mater., 237, 117-122 (2003).

21) F. J. Li, T. Wakihara, J. Tatami, T. Meguro, K. Komeya and K. J. D. MacKenzie, J. Am. Ceram. Soc., 90, 1541-1544 (2007).

22) A. Hendry and K. H. Jack, Special Ceramics, 6, 199-208, Ed. P. Popper (1975).

23) S.-C. Zhang and W. R. Cannon, J. Am. Ceram. Soc., 67[10], 691-695 (2006).

24) S. A. Siddipi and A. Hendry, J. Mater. Sci., 20, 3230-3238 (1985).

25) S. I. Shornikov, I. Yu. Archakov, M. M. Shultz and N. V. Borisova, Doklady Chemistry., 383(1-3), 82-85 (2002).

26) K. Komeya, C. Zhang, M, Hotta, J. Tatami, T. Meguro and Y.-B. Cheng., J. Am. Ceram. Soc., 83, 995-997 (2000).

27) J. Tatami, M. Iguchi, M, Hotta, C. Zhang, K. Komeya, T. Meguro, M. Omori, T. Hirai, M. E. Brito and Y.-B. Cheng., Key. Eng. Mater., 237, 105-110 (2003). 